Jurnal Evaluasi Pendidikan, Vol.2, No. 1, Maret 2011, 30-41

http://doi.org/10.21009/JEP

\title{
PROGRAM EVALUATION ON JOB TRAINING FOR PRE POSITION LEVEL III
}

\author{
Juanda \\ Widyaiswara Balai Diklat Keagamaan (BDK) Jakarta \\ Jl. Rawa Kuning Pulogebang, Jakarta \\ juanda_kasim@hotmail.com \\ DOI: doi.org/10.21009/JEP.021.03
}

\begin{abstract}
The objective of this research is to explore the effectiveness of the third level civil servant pre-service training. This research was conducted at Balai Diklat Keagamaan Jakarta, involving 800 pre-service teachers of MORA's school. This research uses Kirkpatrick's model of evaluation. The research presented four conclusions. Firstly, only $43 \%$ of the instructors' performances are good. Secondly $64 \%$ of the materials are not correlative with the participants' requirements. Thirdly, the equipments of the training are good rate. The fourth, the goal of the training as to improve the participants' knowledge and skill that related to their job are very low (36\%), but attitudes changed due to the training are good (60\%).
\end{abstract}

Keywords: evaluation, the civil servant pre-service training, kirkpatrick's model 


\title{
EVALUASI PROGRAM DIKLAT PRAJABATAN GOLONGAN III
}

\author{
Juanda \\ Widyaiswara Balai Diklat Keagamaan (BDK) Jakarta \\ Jl. Rawa Kuning Pulogebang, Jakarta \\ juanda_kasim@hotmail.com
}

\begin{abstract}
Abstrak
Evaluasi program ini bertujuan meneliti efektivitas Diklat Prajabatan Golongan III di Balai Diklat Keagamaan Jakarta. Penelitian ini dilakukan pada tahun 2007, 2008 dan 2009 dengan jumlah subjek penelitian sebanyak 800 guru CPNS di Kementerian Agama wilayah Prop. DKI Jakarta, Banten dan Kalimantan Barat. Metode yang digunakan dalam penelitian ini adalah studi kasus (case study) dengan tahapan evaluasi dan analisis data mengacu pada model evaluasi program Kirkpatrick. Penelitian menghasilkan beberapa temuan antara lain: 43\% performansi widyaiswara dalam kategori baik, $64 \%$ materi pembelajaran tidak sesuai dengan kebutuhan peserta, sarana pembelajaran termasuk dalam kategori baik dan memadai, serta pencapaian tujuan pembelajaran untuk membekali peserta dengan pengetahuan yang cocok dengan unit kerja peserta sangat rendah hanya $36 \%$, namun perubahan perilaku kerja peserta cukup baik yaitu sebesar $60 \%$.
\end{abstract}

Kata kunci: evaluasi, diklat prajabatan, model evaluasi kirkpatrick

\section{PENDAHULUAN}

Pendidikan dan Latihan (Diklat) merupakan kegiatan untuk memperoleh pegawai negeri sipil yang lebih berkualitas dan memiliki sikap mental yang baik, perilaku yang jujur, disiplin serta penuh pengabdian, sehingga dapat meningkatkan pelayanan dan pengayoman kepada masyarakat dengan sebaikbaiknya.

Penyelenggaraan dan pelaksanaan Diklat Prajabatan telah diatur oleh Lembaga Administrasi Negara. Sebagai lembaga pembina diklat bagi seluruh lembaga diklat yang ada di sistem Pemerintahan Indonesia, Lembaga Administrasi Negara juga mengamanatkan perlu adanya evaluasi dalam penyelenggaraan diklat yang dilakukan oleh lembaga diklat tersebut. Evaluasi ini diharapkan dapat mengetahui efektivitas, tingkat capaian kinerja penyelenggara dan permasalahan yang terjadi diseputar penyelengaraannya. Permasalahan yang terjadi dalam penyelenggaraan Diklat Prajabatan dapat diklasifikasikan kedalam dua faktor, yaitu faktor eksternal dan faktor internal.

Faktor eksternal meliputi: (1) keterlambatan terbit surat keputusan (SK) pengangkatan bagi calon Pegawai Negeri Sipil sebagai syarat administrasi untuk bisa mengikuti Diklat Prajabatan. Hal ini mengakibatkan calon pegawai menunggu cukup lama untuk mendapatkan giliran Diklat Prajabatan, (2) permasalahan yang berkaitan dengan aspek pembelajaran seperti modul yang 
digunakan sudah kadaluarsa atau modul belum dikeluarkan oleh Lembaga Administrasi Negara, tetapi materi (mata diklat) tersebut sudah harus diajarkan, dan (3) tidak sesuai data peserta diklat prajabatan yang dikirimkan oleh kantor wilayah Kementerian Agama propinsi dengan data yang ada di balai diklat keagamaan Jakarta.

Faktor internal meliputi: (1) keterkaitan durasi (alokasi waktu) belajar dengan banyaknya materi yang harus diberikan, (2) waktu belajar dengan karakteristik materi pembelajaran, (3) tingkat kecocokan dan keterpakaian materi di tempat kerja peserta, (4) performansi (tampilan) tenaga pengajar atau widyaiswara, (5) prasarana pembelajaran yang tersedia, dan (6) kompetensi widyaiswara yang belum sesuai dengan mata diklat yang harus diajarkan.

Dengan berbagai permasalahan yang ada sudah seharusnya perlu dilakukan kegiatan evaluasi untuk melihat efektivitas penyelengaraan diklat. Namun demikian kegiatan evaluasi seperti ini jarang dilakukan oleh lembaga penyelenggara diklat termasuk oleh Lembaga Administrasi Negara sebagai instansi pembina lembaga diklat Kementerian Agama.

Balai Diklat Keagamaan Jakarta sebagai penyelenggara diklat calon pegawai negeri sipil di lingkungan Kementerian Agama wilayah DKI Jakarta, Propinsi Banten dan Propinsi Kalimantan Barat, maka perlu mengadakan evaluasi kegiatannya sebagai bentuk pertanggungjawaban publik terhadap stakeholder dan rencana peningkatan pemberian layanan terhadap pengguna. Sebagaimana dikutip oleh Stufflebeam (1986) bahwa evaluasi merupakan suatu proses menggambarkan, memperoleh dan menyajikan informasi deskripitif dan bersifat memutuskan tentang kelayakan dan kebermanfaatan tujuan-tujuan, rancangan, implementasi dan dampak suatu program dalam rangka memberi masukan bagi pembuat keputusan, melayani kebutuhan-kebutuhan akuntabilitas dan mempromosikan pemantauan terhadap fenomena yang terkait. Hal ini juga selaras dengan amanat pedoman umum pendidikan dan pelatihan jabatan yang dikeluarkan oleh Kepala Lembaga Administrasi Negara Republik Indonesia.

Selain itu perlu dilihat apakah materi diklat (mata diklat) yang diberikan sesuai dengan kebutuhan peserta diklat dan seberapa besar tingkat kebermanfaatannya di lapangan, karena peserta prajabatan golongan III di Balai Diklat Keagamaan Jakarta tidak hanya tenaga administrasi tetapi juga pengawas, penyuluh, dosen dan guru. Hal ini tampak berlawanan dengan kurikulum dan mata diklat yang persiapkan oleh Lembaga Adminitrasi Negara lebih cenderung kepada tenaga administrasi.

Berdasarkan tujuan Diklat Prajabatan Golongan III yang tercantum pada Peraturan Pemerintah Nomor 101 Tahun 2000 dan sejalan dengan tujuan diklat atau pelatihan sebagaimana yang dikemukakan oleh Ridha (2006: 6) bahwa lembaga diklat bertujuan untuk membekali peserta dengan kompetensi yang dibutuhkannya. Oleh karena itu perlu pengkajian lebih lanjut akan kecocokan mata diklat (materi) dan kebutuhan peserta yang mayoritas adalah guru-guru 
madrasah, sedangkan materi yang didapat tidak ada yang berkaitan langsung dengan kompetensi mereka sebagai seorang guru.

Dalam evaluasi ini tidak hanya akan diketahui bagaimana produk yang dihasilkan, tetapi juga dampak diklat terhadap tempat kerja yang mengirimkan calon pegawainya untuk di diklat di Balai Diklat Keagamaan (BDK) Jakarta.

Evaluasi program ini bertujuan meneliti efektivitas Diklat Prajabatan Golongan III di Balai Diklat Keagamaan Jakarta. Penelitian ini dilakukan pada tahun 2007, 2008 dan 2009 dengan jumlah subyek penelitian sebanyak 800 guru CPNS di Kementerian Agama wilayah Prop. DKI Jakarta, Banten dan Kalimantan Barat. Metode yang digunakan adalah studi kasus (case study) dengan tahapan evaluasi mengacu pada model evaluasi program Kirkpatrick dengan tahapan: evaluasi reaksi, evaluasi hasil belajar (learning), evaluasi perilaku kerja (behavior), dan evaluasi dampak (result).

\section{METODE PENELITIAN}

Penelitian dilakukan di Balai Diklat Kegamanan Jakarta pada tahun 2007, 2008 dan 2009. Metode penelitian yang digunakan adalah studi kasus (case study). Secara umum metode studi kasus diperlukan pada saat timbul pertanyaan bagaimana dan mengapa pada suatu fenomena sosial yang akan diteliti (Yin, 1989: 23).

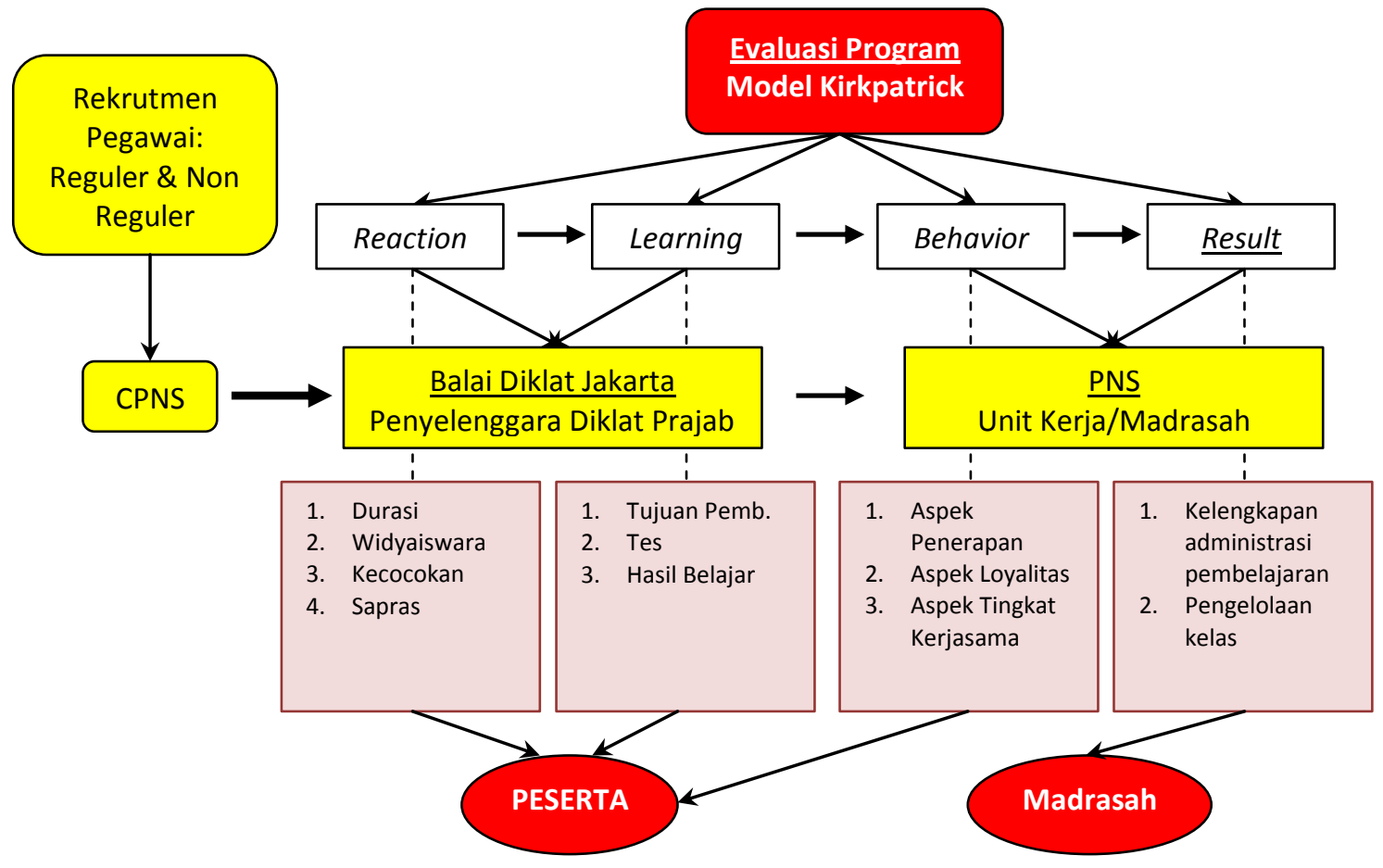

Gambar 1. Evaluasi Program Model Kirkpatrick 
Model yang digunakan adalah Model Kirkpatrick dengan tahapan evaluasi: Pertama, evaluasi reaksi terhadap penyelenggaraan (reaction) pada tahap ini akan diukur tingkat kepuasan peserta (costumer satisfaction) terhadap program diklat yang diikuti, seberapa jauh kebutuhan peserta terhadap program diklat dapat terpenuhi dan bagaimana kualitas faktor pendukung pembelajaran yang mereka terima. Kedua, evaluasi hasil belajar (learning) pada tahap hasil belajar penelitian difokuskan pada hasil pembelajaran yang meliputi pengetahuan dan keterampilan serta kedisiplinan yang diterima peserta dan seberapa jauh penguasaan materi yang mampu dikuasai peserta, serta diadakan pencocokan terhadap hasil belajar yang diharapkan dengan tujuan diklat secara umum. Tahap ini dipengaruh oleh tahap reaksi peserta terhadap program yang diikuti, karena reaksi positif terhadap program berpengaruh positif juga terhadap pembelajaran. Ketiga, evaluasi perilaku kerja (behavior) untuk mengukur perubahan perilaku dan sikap peserta sebagai dampak dari penerapan ilmu hasil pembelajaran yang diikuti dalam diklat. Pada tahap ini akan dilihat seberapa jauh perubahan perilaku alumnus dan dalam hal apa perubahan tersebut terjadi sebagai akibat dari pembelajaran yang diterima selama diklat pra jabatan golongan III. Ini berarti tahap pembelajaran berpengaruh terhadap tahap perilaku. Perubahan perilaku ini akan terdeteksi dalam hal, antara lain implementasi ilmu dalam pekerjaan, dan tingkat kerja sama sebagai dampak dari pengetahuan dan keterampilan baru yang mereka terima dari program diklat. Tahap ini dievaluasi ketika peserta sudah kembali ke unit kerjanya dan telah kembali bekerja seperti biasanya dalam kurun waktu tertentu. Keempat, evaluasi dampak (result) untuk mengukur pengaruh diklat terhadap unit kerja peserta. Dampak diklat ini merupakan hasil atau produk dari tahap penerapan pengetahuan hasil diklat pada evaluasi perilaku kerja (behavior). Sebagaimana yang dinyatakan oleh Philips (1987: 125) bahwa komponen dampak (result) merupakan pengaruh atau dampak langsung diklat terhadap organisasi atau tempat kerja peserta, karena subjek penelitian merupakan guru, maka dampak yang ditimbulkan terhadap unit kerja (madrasah) meliputi (1) kualitas dan kelengkapan administrasi pembelajaran yang dibuat, dan (2) teknik pengelolaan kelas.

Tahap evaluasi behavior dan result ini yang cukup sulit dilakukan karena penelitian dilakukan di unit kerja, setelah peserta kembali ke unit kerjanya masing-masing, sehingga perlu penelitian yang lebih teliti apakah perubahan yang terjadi karena diklat atau pengaruh lingkungan sebagaimana yang disinyalir oleh Nickols. Untuk memperjelas fokus tahapan evaluasi disajikan desain evaluasi yang merupakan modifikasi dari model Nickols (2000: 3) yang disesuaikan dengan Program Diklat Prajabatan Golongan III di Balai Diklat Keagamaan Jakarta.

Evaluasi dilakukan untuk menjawab pertanyaan dan untuk menerapkan kriteria didalam menentukan nilai atau kebermaknaan sesuatu. Pertanyaanpertanyaan evaluasi memberikan arah dan dasar pelaksanaan evaluasi, tanpa itu 
evaluator akan kehilangan fokus yang diharapkan. Oleh karena itu kriteria evaluasi dibutuhkan untuk mendefinisikan ciri-ciri keberhasilan suatu program dan dijadikan alat untuk memberikan keputusan keberhasilan suatu program. Inilah yang dijadikan sebagai kriteria (standar) suatu evaluasi.

Namun demikian, dalam pelaksanaan evaluasi dimungkinkan adanya penggabungan isu-isu baru, pertanyaan dan kriteria. Oleh karena itu evaluator dituntut untuk fleksibel dalam memodifikasi dan memberikan tambahan pada evaluation plan, ketika hal tersebut dibutuhkan. Worten, Sanders dan Fitzpatrick (1997: 5) menambahkan bahwa kriteria atau standar yang dibuat bisa mutlak atau relatif tergantung kebutuhan.

Teknik pengumpulan data disesuaikan dengan komponen data yang dicari yaitu dengan menggunakan angket, wawancara, inventory check list dan lembar observasi serta studi dokumen, diskusi panel dan analisis hasil tes. Untuk mendukung data hasil angket akan dilakukan triangulasi yaitu melakukan dialog langsung kepada subyek yang berkaitan dengan informasi yang dibutuhkan (triangulasi sumber dan metode). Dalam hal ini dilakukan wawancara kepada peserta dan personil pengelola atau penyelenggara diklat pada waktu diklat masih berlangsung serta dilakukan wawancara terbuka ketika peserta sudah kembali ke unit kerjanya (triangulasi waktu).

Instrumen reaksi (reaction) menggunakan instrumen angket, dan inventory check list; instrumen hasil belajar menggunakan studi dokumen; instrumen perilaku kerja menggunakan instrumen angket; dan instrumen dampak menggunakan instrumen angket dan wawancara.

\section{HASIL PENELITIAN DAN PEMBAHASAN}

\section{Evaluasi Reaksi terhadap Kegiatan Diklat}

Durasi (rentang) diklat dan waktu belajar yang dilaksanakan untuk Diklat Prajabatan Golongan III eks honorer yang lebih lama dari Diklat Prajabatan Golongan III reguler, yaitu 24 hari dengan penambahan 3 mata diklat baru, ratarata jawaban peserta mendekati kategori baik. Hal ini juga diperkuat oleh komentar peserta yang ditulis pada angket yang diberikan, peserta menyatakan bahwa waktu 24 hari memungkinkan untuk mendalami mata diklat yang diberikan, sehingga alumni berpendapat waktu tersebut cukup memadai untuk materi yang tersedia. Namun demikian ada 5\% peserta menanggapi rentang diklat dan waktu belajar dalam kategori kurang baik, karena mereka menganggap perlu waktu yang lebih lama didalam mempelajari materi yang diberikan, sedangkan dari jadwal yang ada terlalu dipaksakan dan terlalu padat. Rata-rata setiap hari kegiatan baru berakhir pada pukul 21.15 WIB.

Untuk reaksi peserta terhadap komponen yang berkaitan dengan kecocokan materi dengan kebutuhan peserta sebagai tenaga pendidik, 60\% responden menjawab kurang, karena materi yang disajikan lebih banyak mengenai kepegawaian, namun demikian peserta mendapatkan materi tentang penataan persuratan dan kearsipan (Mata Diklat Manajemen Perkantoran 
Modern) yang berguna didalam melakukan penataan dan kelengkapan administrasi pembelajaran.

Tanggapan atau reaksi peserta terhadap performansi widyaiswara seperti penguasaan materi, metode pembelajaran dan media pembelajaran serta pencapaian tujuan pembelajaran. $13 \%$ peserta (responden) menyatakan performansi widyaiswara kurang, hanya $43 \%$ responden menjawab baik dan $38 \%$ menjawab sedang serta ada $8 \%$ peserta menjawab bahwa performansi widyaiswara dalam kategori sangat baik dan dapat dijadikan contoh model pembelajaran serta pengelolaan kelas yang baik. Berdasarkan hasil wawancara terhadap peserta diperoleh data bahwa widyaiswara tidak hanya menjelaskan secara teori tentang model dan teknik pembelajaran, tetapi widyaiswara juga memberikan contoh dengan menampilkan model dan teknik pembelajaran di kelas. Alumni mendapatkan teknik pembelajaran dan pengelolaan alat bantu seperti LCD, flip chart, contoh ice breaker (tayangan penyegar suasana) dan selingan untuk membangkitkan motivasi peserta dalam belajar. Widyaiswara dapat membangkitkan minat alumni untuk menggunakan ICT dalam pembelajaran setelah melihat widyaiswara menggunakan dalam pembelajaran. Namun demikian alumni juga menemukan ada widyaiswara yang kurang menguasai bahan pembelajaran, terlalu monoton atau terpaku dengan tayangan (power point slide). Hal ini memberikan contoh langsung kepada alumni tentang perlunya persiapan sebelum melakukan kegiatan pembelajaran, sehingga tidak tergantung kepada media yang digunakan.

Kelengkapan sarana dan prasarana pembelajaran sudah cukup memenuhi standar kelayakan untuk melakukan pembelajaran yang kondusif. Data hasil wawancara terungkap bahwa ada beberapa hal yang membuat diklat prajabatan kurang efektif antara lain pemahaman panitia terhadap diklat masih perlu ditingkatkan, sebagai contoh tidak dipakainya daftar simak (daftar inventarisir kegiatan yang telah dilakukan) dalam setiap kegiatan diklat, sehingga sulit untuk mengontrol apa saja kegiatan yang telah dilakukan atau belum, kurang jumlah widyaiswara sehingga dua atau tiga mata diklat dipegang oleh satu orang. Namun demikian ada kelebihan diklat prajabatan seperti latihan materi baca AlQur'an, sholat subuh berjamaah dan ceramah subuh. Kegiatan ektra ini menambah wawasan dan kekompakan di antara peserta dan panitia.

\section{Evaluasi Pembelajaran}

Pada tahap ini evaluator meneliti pengetahuan, keterampilan, sikap dan perilaku serta hasil belajar yang diharapkan dari pembelajaran tersebut. Hal ini penting karena keberhasilan dari tahapan berikutnya yaitu tahap perilaku kerja (behavior) dan dampak (result) tidak akan terjadi apabila tujuan pembelajaran tidak tercapai dengan optimal. Kemudian diadakan juga penilaian terhadap kelayakan silabus, kurikulum dan soal yang digunakan dalam ujian.

Dalam aspek keterampilan alumni mendapatkan model pembelajaran dari tampilan dan performansi widyaiswara dalam pembelajaran. Alumni 
mendapatkan contoh langsung metode pembelajaran, seperti penguasaan kelas, cara menggunakan alat bantu pembelajaran (ICT), flipt chart, ice breaker (tayangan penyegar susana) dan selingan untuk membangkitkan minat serta perhatian peserta terhadap pembelajaran. Juga mendapatkan contoh langsung dalam melakukan kegiatan diskusi yang efektif dan benar serta metode untuk meng-aktifkan atau melibatkan peserta dalam pembelajaran. Untuk kedisplinan mereka mendapatkan itu dalam kegiatan ekstrakurikuler yaitu pembelajaran baris berbaris, latihan upacara dan disiplin waktu dalam jadwal kegiatan pembelajaran maupun dipupuknya rasa kebersamaan dan toleransi melalui kegiatan kuliah subuh, sholat berjamaah dan kegiatan kerohanian.

Untuk menguji kemampuan peserta diklat prajabatan dalam penguasaan materi diklat, maka diadakan dua tahap ujian (ujian I dan ujian II). Soal ujian baik ujian I dan II terdiri dari pilihan ganda, menjodohkan, isian dan uraian. Semenjak tahun 2010 soal ujian hanya berupa pilihan ganda yang berjumlah 100 butir soal. Soal ujian merupakan kumpulan butir soal dari 14 mata diklat yang diajarkan. Namun demikian soal ujian yang digunakan baik untuk peserta Diklat Prajabatan Golongan II dan III, tidak terdapat perbedaan yang jelas, sedangkan waktu dan kedalaman materi berbeda antara kedua diklat ini. Validitas konstruk soal ujian rendah, butir ujian dari tahun ketahun tidak berubah baik ujian I maupun ujian II, ada kecenderungan hanya membolak balik butir soal antara kedua ujian tersebut.

Namun demikian tingkat kelulusan tinggi, karena hasil ujian hanya berpengaruh sebesar $40 \%$ terhadap kelulusan, sedangkan yang $60 \%$ sangat dipengaruhi oleh faktor sikap, perilaku dan keaktifan peserta. $60 \%$ tersebut terdiri dari penilaian prakarsa (12\%), tingkat kerja sama (12\%), kedisiplinan selama mengkuti diklat (24\%) dan kepemimpinan didalam kelompok belajar (12\%). Berdasarkan sistem penilaian tersebut persentase kelulusan peserta Diklat Prajabatan Golongan III di Balai Diklat Keagamaan Jakarta selama kurun waktu tahun 2007, 2008 dan 2009 mencapai 99,25\%. Hanya 4 peserta yang tidak lulus karena ada komponen ujian tidak mencapai nilai minimal. Untuk kasus empat peserta ini dilakukan program remedial dalam periode setelah kegiatan diklat usai pada tahun berjalan, sehingga peserta tersebut dapat lulus tanpa harus mengikuti Diklat Prajabatan tahun berikutnya. Berdasarkan keterangan dari pengelola diklat tahun 2009 ada peserta yang tidak lulus setelah mengikuti dua kali diklat prajabatan sehingga peserta tersebut tidak bisa diangkat menjadi pegawai negeri sipil.

Berkaitan dengan hasil ujian, maka perlu adanya pelatihan bagi pembuat soal tentang bagaimana membuat soal yang sesuai dengan aturan pengukuran dan dapat dipertanggungjawabkan, baik secara konten maupun butir tes yang digunakan. Dalam hal ini penyelenggara diharuskan memiliki bank soal yang menampung berbagai soal ujian yang telah melalui proses uji coba, karena masih ditemukan soal ujian untuk Diklat Golongan II sama dengan soal ujian untuk golongan III. 
Jurnal Evaluasi Pendidikan, Vol.2, No. 1, Maret 2011, 30-41

http://doi.org/10.21009/JEP

\section{Evaluasi Perilaku Kerja}

Hasil Diklat Prajabatan Golongan III, mengharapkan peserta mempunyai kemampuan untuk menerapkan ilmu yang dapat digunakan langsung didalam pekerjaannya dan perubahan perilaku serta kepedulian terhadap tingkat perubahan dan kesinambungannya. Perilaku kerja (behavior) juga fokus pada faktor kerja sama yang meliputi cara bersosialisasi dengan teman dan atasan, mau dan mampu bekerja secara bersama, mau menerima dan memberi saran, serta tidak memaksakan kehendak. Dari hasil angket yang terdiri dari 25 butir pertanyaan, terungkap bahwa penerapan ilmu hasil diklat secara umum termasuk dalam ketegori sedang. Hal ini dikarenakan sebagian besar materi tidak berkaitan dengan tugas dan fungsi peserta sebagai guru atau pendidik. Penerapan hasil pembelajaran berdasarkan pendapat atasannya sangat kecil, $53 \%$ dalam kategori rendah. Penggunaan ilmu yang didapat dan langsung berkaitan dengan tugas dan fungsi alumni sebagai guru hanya beberapa mata diklat saja yang dapat diterapkan langsung dalam kegiatan pembelajaran.

Untuk evaluasi penerapan aspek perubahan perilaku kerja termasuk kategori baik. Aspek ini mencakup: (1) kedisiplinan, (2) loyalitas dan persepsi terhadap pekerjaan, serta (3) inisiatif yaitu kemampuan alumni memberi saran dan gagasan untuk kemajuan unit kerja serta penerapan idea baru dalam bekerja. Evaluasi penerapan dalam aspek perubahan perilaku kerja (behavior) yang berkaitan dengan tingkat kerjasama dan prakarsa dalam kategori baik, misalnya kemauan dan menerima saran. Demikian juga evaluasi penerapan dalam aspek perubahan perilaku kerja (behavior) yang berkaitan dengan tingkat kerjasama dan prakarsa dalam kategori baik, misalnya kemauan untuk memberi dan mene-rima saran termasuk kategori baik. Akan tetapi dalam hal kepedulian dan kesi-nambungan untuk meneruskan perubahan yang terjadi sebagai dampak diklat termasuk dalam kategori rendah.

\section{Evaluasi Dampak}

Sebagaimana yang dinyatakan oleh Philips bahwa komponen hasil (result) merupakan dampak langsung diklat terhadap organisasi atau tempat kerja peserta, karena subjek penelitian merupakan guru, maka dampak yang ditimbulkan terhadap unit kerja yakni madrasah meliputi: (1) produk yang dihasilkan berupa perangkat administrasi pembelajaran, (2) teknik pengelolaan kegiatan belajar mengajar. Berdasarkan angket yang diberikan kepada atasan alumni diklat dalam hal ini kepala madrasah diperoleh data bahwa secara keseluruhan dari indikator dampak tersebut setelah diuraikan kedalam 22 butir pertanyaan, maka dampak yang ditimbulkan secara umum termasuk dalam kategori sedang. Untuk produk yang dihasilkan alumni berupa perangkat administrasi pembelajaran ditemukan bahwa setelah mengikuti diklat prajabatan alumni cenderung untuk melengkapi dan membuat perangkat administrasi pembelajaran lebih baik tidak asal jadi seperti sebelumnya. Kegiatan pembelajaran termasuk kategori sedang berdasarkan hasil pengamatan terhadap 
performasi alumni di dalam kelas. Hal ini terjadi karena dalam Diklat Prajabatan Golongan III tidak ada materi khusus yang berkaitan langsung dengan tugas dan fungsi guru sebagai pendidik. Peserta hanya mendapatkan model pembelajaran dan tampilan widyaiswara pada saat memberikan pembelajaran.

\section{SIMPULAN}

Secara umum pelaksanaan Diklat Prajabatan Golongan III di Balai Diklat Keagamaan Jakarta untuk guru mantan honorer termasuk dalam rentang sedang sampai baik. Namun demikian ditemukan hal-hal yang masih perlu perbaikan seperti belum diberikan materi diklat yang berkaitan dengan keguruan, misalkan materi pedagogik dan metodologi pembelajaran. Hal ini perlu untuk memberikan bekal kepada peserta, sehingga pengaruh Diklat Prajabatan tidak hanya cenderung kepada tataran sikap dan kedisiplinan, tetapi juga pada kompetensi yang melekat pada diri peserta diklat yang menjadi tanggung jawabnya di lapangan.

Berdasarkan reaksi atau tanggapan peserta terhadap pelaksanaan program diklat yang berkaitan dengan durasi Diklat Prajabatan Golongan III selama 24 hari secara umum peserta menganggap penambahan waktu masih dalam batas yang ditolerir.

Untuk komponen yang berkaitan dengan kecocokan materi dengan kebutuhan di unit kerja, maka banyak materi yang tidak aplikatif bagi peserta yang bukan tenaga administrasi (dalam hal ini peserta sebagai guru). Ini berarti untuk peserta yang merupakan guru tidak mendapatkan materi yang berkaitan langsung dengan kebutuhan mereka di lapangan. Karena hampir sebagian materi (mata diklat) lebih cocok untuk peserta yang bertugas sebagai tenaga administrasi. Walaupun mereka mendapat model pembelajaran secara tidak langsung dari penampilan atau performansi widyaiswara. Namun ada beberapa temuan yang perlu menjadi pertimbangan penyelenggara, yaitu beban mengajar untuk masing-masing widyaiswara masih terlalu banyak yaitu tiga sampai empat mata diklat. Hal ini akan mempengaruhi kesiapan dan kualitas pembelajaran.

Dalam hal ketersediaan sarana dan prasarana pembelajaran sudah cukup memenuhi standar kelayakan untuk melakukan pembelajaran yang kondusif. Namun demikian perlu adanya penambahan tempat ibadah (musholla) yang khusus, poliklinik kesehatan dan perpustakaan yang selalu siap untuk diakses.

Dari hasil penelitian bahwa dalam diklat prajabatan golongan III untuk mantan honorer adalah 13 mata diklat yang diajarkan dan ditambah dengan materi ekstrakurikuler. Hal ini sudah cukup memadai untuk pembentukan karakter dan perilaku PNS, namun demikian yang berkaitan dengan pengetahuan perlu adanya regulasi mata diklat untu peserta diklat yang bukan tenaga administrasi, sehingga peserta diklat (guru) juga mendapat materi pedagogik dan metodologi pembelajaran. Untuk hal yang berkaitan dengan penguasaan materi secara kog-nitif sudah cukup tinggi, tapi perlu adanya analisis secara mendalam 
terhadap butir-butir soal yang digunakan, sehingga tingkat validitas dan reliabilitas dapat lebih ditingkatkan.

Penerapan hasil pembelajaran yang diperoleh dan perubahan yang ditimbulkan hanya dalam kategori sedang, ini berarti penggunaan ilmu yang didapat hanya sebagian kecil atau dengan kata lain hanya ilmu tertentu seperti komunikasi efektif, kerja sama kelompok (team building) dan pelayanan prima yang dapat diterapkan dalam kegiatan pembelajaran. Namun demikian penerapan atau transfer ilmu yang berkaitan dengan kerjasama dan prakarsa terhadap pekerjaaan, berdasarkan pendapat rekan kerja termasuk dalam kategori tinggi. Ini berarti setelah mengikuti diklat alumni lebih cenderung terbuka dan siap untuk bekerja sama membantu rekannya di dalam bekerja.

Untuk perubahan perilaku yang meliputi kebiasaan kerja yaitu tingkat kehadiran dan ketepatan waktu menunjukan rata-rata perubahan yang cukup baik, sedangkan iklim kerja meliputi kepuasan dalam bekerja dan suasana kerja dalam kategori sedang, sikap dan persepsi alumni terhadap pekerjaan cenderung lebih baik dan lebih tinggi, serta inisiatif yang diberikan lebih intensif dan berbobot.

Dampak langsung terhadap unit kerja yang meliputi produk yang dihasilkan; berupa perangkat administrasi pembelajaran, setelah diklat prajabatan menunjukan perbaikan, lebih lengkap, dan berkualitas. Begitu juga dengan penggunaan biaya dan waktu cenderung lebih bertanggung jawab. Demikian juga teknik pengelolaan Kegiatan Belajar Mengajar (KBM) termasuk dalam kategori sedang, dilihat dari hasil pengamatan (observasi) terhadap tampilan atau performansi guru (alumni) di dalam kelas mulai dari persiapan mengajar sampai dengan menutup pembelajaran. Hal ini terjadi karena dalam Diklat Prajabatan Golongan III tidak ada materi khusus yang berkaitan langsung dengan tugas dan fungsi guru dalam kegiatan pembelajaran. Peserta hanya mendapatkan model pembelajaran dari tampilan widyaiswara dalam memberikan pembelajaran. Dari tampilan tersebut terdapat contoh didalam pengelolaan kelas, penggunaan media pembelajaran dan teknik diskusi yang efektif.

\section{DAFTAR PUSTAKA}

Kirkpatrick, L. Donald dan James D. Kirkpatrick. (2005). Evaluating Training Programs: The Four Levels, Third Edition. San Francisco: Berrett-Koehler Publishers Inc.

. (2008). "Kirkpatrick's Learning and Training Evaluation Theory," http://www. kirkpatricklearningevaluationmodel.html. 
. (2008). "Instructional System Development - Evaluation Phase - Chapter IV", http://www.newlink.com/ donclark/hrd/sat6.html.

Nickols, Fred. (2000). "Evaluating Training There is no 'cookbook' approach". http://www.nickols.us/evaluating_training.pdf.

Philip, Jack J. (1987). Recruiting, Training, And Retraining New Employees, Managing the Transition From College to Work. California: Jossey Bass Inc.

Ridha, Akram. (2006). Becoming A Super Trainer. Bandung: Progressio.

Stufflebeam, Daniel L., dan Anthony J. Shinkfield. (1986). Systematic Evaluation: A Self- Instructional Guide to Theory and Practice. Dordrecht: KluwerNijhoff Publishing.

Yin, Robert K. (1989). Case Study Research Design and Methods. London: Sage Publications.

Worten, Blaine R., James R. Sanders, dan Jody L. Fitzpatrick. (1997). Program Evaluation Alternative Approaches and Practical Guidelines, Second Edition. New York: Wesley Longman Inc.

Lembaga Administrasi Negara RI. (2006). Kebijakan LAN tentang Diklat Struktural dan Teknis Fungsional. Jakarta: LAN.

. (2007). Himpunan Peraturan Kepala Lembaga Administrasi Negara Nomor: 2, 3, 4, dan 5 Tahun 2007. Jakarta: LAN. 